\title{
Sensitivity of Colletotrichum species responsible for banana anthracnose disease to some fungicides used in postharvest treatments in Côte d'Ivoire
}

\author{
Luc BELE $^{1}$, Daniel Kra Kouamé ${ }^{1}$, Hortense Diallo Atta ${ }^{1}$ \\ Unité santé des plantes, Université Nangui Abrogoua, Côte d'Ivoire
}

\begin{abstract}
Anthracnose is a major postharvest disease of banana fruit in Côte d'Ivoire. Colletotrichum musae is usually associated with banana anthracnose disease. Persistent symptoms of anthracnose despite the postharvest treatment requires accurate characterization of pathogens for effective control. The present study was conducted to identify the species of Colletotrichum responsible for banana anthracnose and test their sensitivity to fungicides. The morphological study and molecular identification of isolated species associated with anthracnose symptoms had identified Colletotrichum gloeosporioides and Colletotrichum musae. Pathogenicity tests with representative isolates were conducted on symptomless banana fruits. All tested isolates caused anthracnose lesions on banana fruit, however C. musae was significantly more aggressive than $C$. gloeosporioides. Sensitivity tests including imazalil, azoxystrobin and boscalid showed a sensitivity of $C$. musae and C. gloeosporioides to imazalil. However, a resistance of both species to azoxystrobin and boscalid was recorded. This study highlighted the presence of resistants strains of Colletotrichum responsible for anthracnose in Côte d'Ivoire.
\end{abstract}

Keywords- Banana, Anthracnose, C. musae, C. gloeosporioides, Sensitivity

\section{INTRODUCTION}

Banana is an economically important crop in tropical and subtropical regions. Côte d'Ivoire is one of the main African producers of banana dessert. The bulk of Ivorian production is destined for the European market with an estimated export volume of 330460 tons in 2014 (Faostat, 2016).

However, fungal diseases are responsible for large losses in the banana production chains, especially during postharvest period. Banana anthracnose is considered as one of the most important diseases of banana (Jeffries et al. 1990). Infection on the banana usually starts during the development of the fruit but remains quiescent until the fruit ripens; symptoms often manifest during storage. Symptoms appear as brown or black spots which enlarge depressed with ripening (Ranasinghe et al 2005). Anthracnose deteriorates quality of bananas and causes economic losses for producers and traders (Ara et al. 2012).

In Côte d'Ivoire, anthracnose was found to be recurrent on bananas despite postharvest treatments. Colletotrichum species are agents associated with anthracnose on many tropical and subtropical fruits (Bailey et al 1992). however, only $C$. musae was identified as responsible for banana anthracnose (Stover et al., 1987).

Chemical control methods are the most used strategies against the fungi responsible for banana postharvest diseases (Gang et al., 2015). Chemical control of banana anthracnose includes the use of active ingredients such as benzimidazoles, Strobulirines, and dicarboxamides (Young et al., 2010). However, persistence of banana anthracnose has been noted in recent decades despite antifungal treatment applied by producers in Côte d'Ivoire. Resistant strains to these fungicides have emerged. Indeed, the recurrence of banana anthracnose could be due to intensive monoculture in industrial plantations which could favor the development of new pathogens strains.

The objective of this work was to identify the species of Colletotrichum responsible of banana anthracnose and evaluate their sensitivity to fungicides currently used in postharvest treatment.

\section{MATERIAL AND METHODS}

2.1. Sampling and isolation of Colletotrichum spp. Boxed banana (Cavendish Subgroup, cv. Grande Naine) treated with fungicide were randomly selected at different banana production sites in Côte d'Ivoire (Abengourou, Abgoville, Aboisso Azaguié, Dabou, Grand Bassam and Tiassalé). Banana boxes were placed in storage at the laboratory at room temperature $\left(27 \pm 1^{\circ} \mathrm{C}\right)$ for 21 days and observed daily. During this period, symptoms 
developed on the epicarp were observed and described. Banana fruits showing anthracnose symptoms were used for fungi isolation according to the method of Davet and Rouxel (1997). Pure cultures were obtained by single spore isolation carried out using the procedure described by Choi et al (1999), with modifications.

\subsection{Morphological and cultural characterization}

Each isolate from pure cultures was plated onto PDA and incubated at room temperature $\left(27 \pm 1^{\circ} \mathrm{C}\right)$. After 7 days, colony size, shape, margin and colour were recorded. Colony diameter of every culture was recorded daily for 7 days. Growth rate was calculated as the 7-day average of mean daily growth (mm per day). Three cultures of each isolate were investigated and experiments were conducted twice. For examination of conidial morphology, all isolates were subcultered as mentioned above. Cultures were washed with sterile water and drops of the suspension were placed on microscope slides. Length and width were measured for 50 conidia per isolate. Conidial shape (cylindrical or falcate) was also recorded.

\subsection{Pathogenicity Test}

Pathogenicity tests were performed with a representative set of isolates, from all morphological groups, using noninfected matured green unripe banana fruits (Cavendish Subgroup, cv. Grande Naine). Banana fruits were disinfested by immersing them in $1 \% \mathrm{NaOCl}$ solution for $1 \mathrm{~min}$, washed twice with sterile distilled water. The fruits were blotted dry with a sterile paper tissue and inoculated using the wound/ drop method (Lim et al., 2002; Kanchana-udomkan et al., 2004). The wound/drop method involved pin-pricking the surface of the fruit to a $1 \mathrm{~mm}$ depth and then placing $10 \mu \mathrm{l}$ of conidial suspension $\left(1 \times 10^{6}\right.$ spores $\left.\mathrm{ml} / 1\right)$ over the wound. Nine fruits were tested per isolate and experiments were conducted twice. The inoculated fruit, along with appropriate controls (fruit inoculated with sterile distilled water) were placed in storage into sterile plastic containers and incubated at laboratory temperature $\left(27 \pm 1{ }^{\circ} \mathrm{C}\right)$. Symptoms were recorded 5 days after inoculation (d.a.i.) and re-isolation, according to Koch's postulates, was made from all resulting lesions. The lesion diameter was measured 5 days after inoculation and the mean diameter of the lesions was calculated.

\subsection{Molecular characterization}

\subsubsection{DNA extraction}

Total genomic DNA was extracted from fungal mycelium grown on potato dextrose agar (PDA) following the protocol of Murray and Thomson. (1980).

\subsubsection{PCR and sequencing}

PCR amplification of the rDNA ITS region was done using the universal primers ITS1 and ITS4 (White et al., 1990) in a thermocycler T 100 (Bio Rad). The following amplification program was used: initial denaturation (5 min at $94^{\circ} \mathrm{C}$ ), followed by 35 cycles each comprising a denaturation step (30 s at $94^{\circ} \mathrm{C}$ ), a step of annealing (30 $\mathrm{s}$ at $\left.55^{\circ} \mathrm{C}\right)$ and an elongation step $\left(30 \mathrm{~s}\right.$ at $\left.72{ }^{\circ} \mathrm{C}\right)$ and a final elongation for $10 \mathrm{~min}$ at $72^{\circ} \mathrm{C}$. The PCR products were migrated at a voltage of $100 \mathrm{~V}$ for $30 \mathrm{~min}$ by electrophoresis in an agarose gel at $1 \%$ in a $0.5 \times \mathrm{TBE}$ buffer (Tris-Borate $90 \mathrm{mM}, 1 \mathrm{mM}$ EDTA) and visualized in a visual reader of EBOX-VX5 brand. The PCR products were purified observed amplicons sequenced Sporometrics, 219 Dufferin Street in Canada.

\subsection{In vitro susceptibility of Colletotrichum species to fungicides}

Three commercial fungicides Bankit, Cumora, Sulima (Table 1) were evaluated in vitro using the poison food technique (Adams and Wong, 1991). Fungicide suspension of $1 \mathrm{ppm}, 10 \mathrm{ppm}, 50 \mathrm{ppm}, 100 \mathrm{ppm}, 500$ ppm, $1000 \mathrm{ppm}$ and $1500 \mathrm{ppm}$ were prepared by dissolving requisite quantities of each fungicide in autoclaved cooled PDA just before pouring into Petri dishes. Fifteen $\mathrm{ml}$ of fungicide amended media was poured into each $9 \mathrm{~cm}$ sterilized Petri dishes. Three replicates were performed for each concentration of each fungicide. Medium without fungicide served as a control. After solidification of the medium, each dish was inoculated with a mycelial disc (5-mm diameter) taken from the periphery of actively growing colonies on PDA. The Petri dishes were incubated in dark at $27 \pm 1^{\circ} \mathrm{C}$ until the control colony reached the margins of the Petri dish. The measurement of the diameter of the mycelial growth of the fungus were recorded on a daily basis, beginning with 24 hours after inoculation. Percent inhibition of growth of Colletotrichum species was recorded using the following formula (1):

$$
\mathrm{I}(\%)=\frac{\mathrm{dc}-\mathrm{dt}}{\mathrm{dc}} \times 100
$$

where, $\mathbf{d c}$ is the average fungal colony diameter measured in control plate, with no treatment, and $\mathbf{d t}$ is the average fungal colony diameter measured in treated dishes

Table.1: Characteristics of fungicides used in banana postharvest treatment

\begin{tabular}{cccc}
\hline $\begin{array}{c}\text { actives } \\
\text { ingredients }\end{array}$ & $\begin{array}{c}\text { commercial } \\
\text { name }\end{array}$ & Groups & Concentration \\
\hline Azoxystrobin & Bankit & Strobulirin & $250 \mathrm{~g} / 1$ \\
Imazalil & $\underline{\text { Sulima }}$ & Imidazol & $750 \mathrm{~g} / 1$ \\
Boscalid & Cumora & Carboxamid & $500 \mathrm{~g} / 1$ \\
\hline
\end{tabular}




\subsection{Statistical analysis}

Analysis of variance (ANOVA) to a classification criterion was performed to compare mean growth of isolates, mean length and width of conidia. The average lesion diameter and susceptibility of fungi to fungicides were also compared. The means were separated using Least Significance Different Test at $p<0.05$. The analyzes were performed using IBM SPSS Statistics 20 software.

\section{RESULTS}

\subsection{Morphological and cultural characterization}

Common morphological characteristics of colonies allowed the grouping of the isolates into two morphological groups (Table 2). Isolates of Group 1 had colonies with reddish slight pink moderate aerial mycelia. The colonies produced by isolates of Group 2 had white colonies with moderate aerial mycelia and copious cinnamon conidial masses (Fig 1). The mean growth rate of the various groups was calculated. There was no significant difference $(\mathrm{P}=0.74)$ in growth rate among isolates of two groups. Isolates of group 1 had growth rates ranging from 4.36 to $4.8 \mathrm{~mm}$ day-1. Isolates from group 2 had growth rates ranging from 4.9 to $5.2 \mathrm{~mm}$ day1. Isolates of group 1 had significantly longer conidia than those of group 2. Isolates of group 1 produced hyaline, cylindrical conidia with acute apex. The average length and width of the conidia were $11.25 \mu \mathrm{m}$ and 2.5 $\mu \mathrm{m}$, respectively. The group 2 conidia were all cylindrical with both ends rounded. The average length and width of the conidia were $23 \mu \mathrm{m}$ and $5.5 \mu \mathrm{m}$, respectively. Isolated belonging to group 1 were confirmed to be $C$. gloeosporioides and isolated of the group 2 were $C$. musae according to morphological and cultural characteristics.

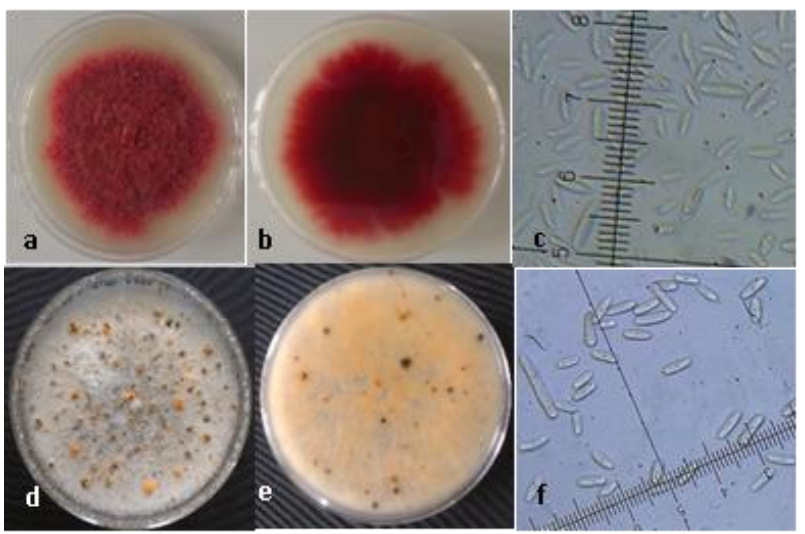

Fig.1: Morphological characteristics of Colletotrichum gloesporioides and C. musae isolated from anthracnose of banana. C. gloeosporioides (a-c): (a) upper surface, (b) lower surface, (c) conidia, C. musae (d-f): (d) upper surface, (e) lower surface, $(f)$ conidia.

\subsection{Molecular identification of Colletotrichum} species

The ITS region, including the 5.8S gene of all isolates was successfully amplified and sequenced. The size of the amplification product obtained was estimated to be 450 bp (Fig 2). Colletotrichum species belonging to group 1 was identified as Colletotrichum gloeosporioides under accession number MG515233.1. Colletotrichum species belonging to the morphological group 2 were identified under the accession number MG515228.1 as Colletotrichum musae.

Table.2: Summary of morphological data for Colletotrichum species

\begin{tabular}{|c|c|c|c|c|c|}
\hline \multirow[t]{2}{*}{ species } & \multirow[t]{2}{*}{ Colony color } & \multicolumn{3}{|c|}{ Conidia (mean) } & \multirow{2}{*}{$\begin{array}{c}\text { Growth rate } \\
\text { (mm/day) }\end{array}$} \\
\hline & & Length $(\mu \mathrm{m})$ & Width $(\mu \mathrm{m})$ & Shape & \\
\hline C. gloeosporioides & $\begin{array}{c}\text { reddish } \\
\text { slight pink }\end{array}$ & 11.25 & 2.5 & $\begin{array}{l}\text { cylindrical with } \\
\text { acute apex. }\end{array}$ & $4.36-4.8$ \\
\hline C. musae & white & 23 & 5.5 & $\begin{array}{l}\text { cylindrical with } \\
\text { both ends } \\
\text { rounded }\end{array}$ & 4.9-5.2 \\
\hline
\end{tabular}




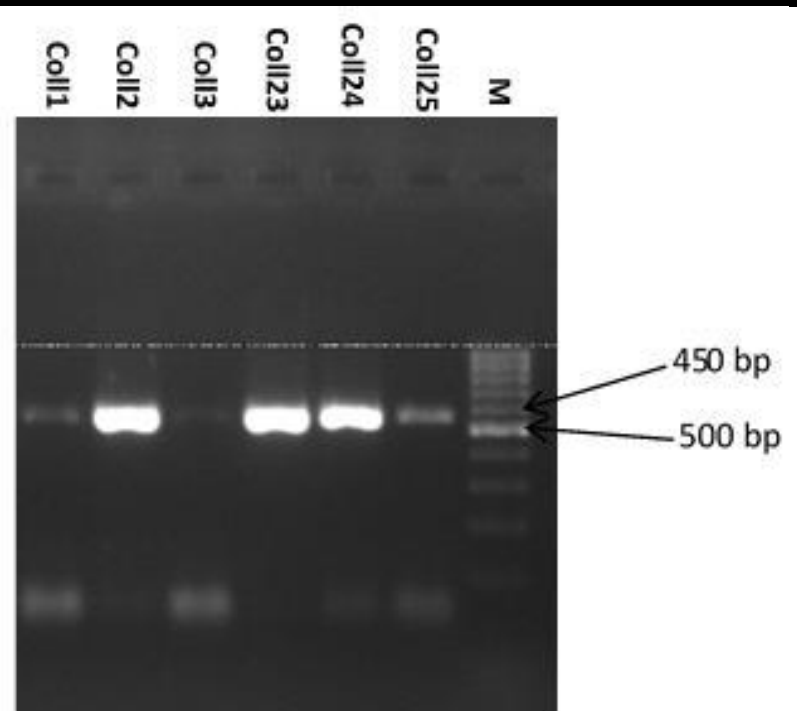

Fig.2: PCR amplification of ITS region of ribosomal DNA of Colletotrichum isolates with primer pairs ITS1 and ITS4

\subsection{Pathogenicity testing}

Characteristic symptoms of anthracnose were developed by all the isolates of Colletotrichum on banana fruits after wound inoculation. Generally, the lesions appeared 3 days post inoculation and expanded rapidly over 3-5 days. Lesions were black necrotic, circular and sunken, and these lesions showed white mycelia growth and produced orange colored conidial masses later. (Fig 3). Infections stimulate ripening of fruits, and lesions enlarge with ripening. Koch's postulates were confirmed by reisolation of the fungi causing the lesions and identification as $C$. musae and $C$. gloeosporioides. Diameter of the anthracnose lesions varied among Colletotrichum isolates significantly $(\mathrm{P}<0.05)$. The highest diameter of lesion was recorded with $C$. musae $(4.03 \mathrm{~cm})$. C. gloeosporioides gave the lowest lesion diameter $(3.01 \mathrm{~cm})$.

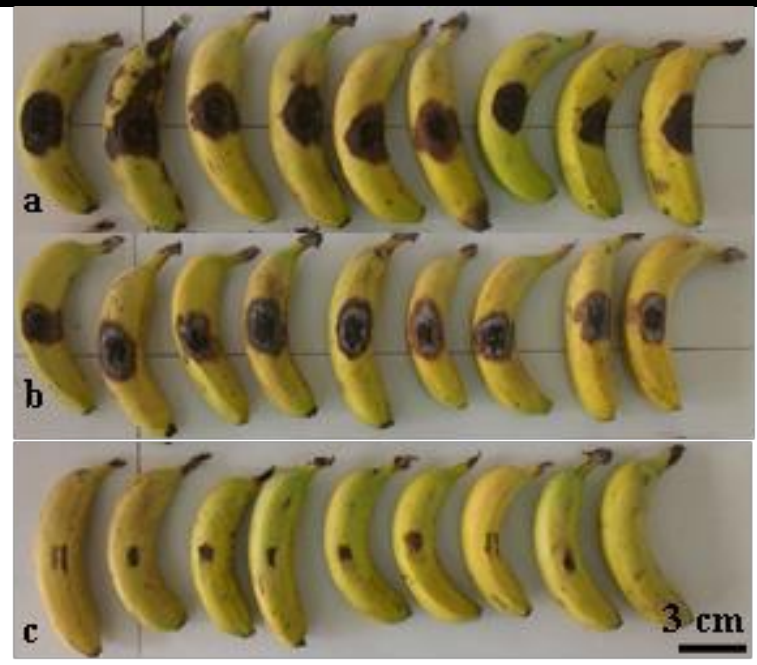

Fig.3: Symptoms of anthracnose disease on banana fruits after wound inoculation: (a): dry dark brown to black lesions with irregular margin and tan-to-orangecolored spores typical of Colletotrichum musae infection; (b):large black lesion with white mycelia typical of $C$. gloeosporioides infection; (c): control

\subsection{In vitro susceptibility of Colletotrichum species} to fungicides

The susceptibility of Colletotrichum species to the various fungicides was presented through the mycelial growth inhibition rates in Table 3. There was a significant difference $(\mathrm{P}<0.05)$ in susceptibility of Colletotrichum species to fungicide. For all fungicides tested, mycelial growth inhibition rate increased at the highest concentrations. Imazalil induced a complete inhibition of the mycelial growth of each species at $100 \mathrm{ppm}$. Imazalil was significantly superior to all the other fungicides followed by Azoxystrobin at all the test concentrations. $C$. musae and C. gloeosporioides were tolerants to Imazalil at concentrations ranging from 100 to $1500 \mathrm{ppm}$. However both Colletotrichum species showed resistance to Azoxystrobin and Boscalid at all the test concentrations.

Table.3: Effect of different fungicides on mycelial growth (cm) of Colletotrichum species. by poisoned food technique after 7

\begin{tabular}{|c|c|c|c|c|c|c|c|c|}
\hline \multirow{3}{*}{ species } & \multirow{3}{*}{ fungicide } & \multicolumn{7}{|c|}{ Percentage inhibition $(\%)$} \\
\hline & & \multicolumn{7}{|c|}{ Concentrations (ppm) } \\
\hline & & 1 & & 10 & 50 & 100 & 1000 & 1500 \\
\hline \multirow{3}{*}{ C. musae } & Imazalil & $38^{\mathrm{b}}$ & $58^{\mathrm{b}}$ & $60^{\mathrm{b}}$ & $100^{\mathrm{a}}$ & $100^{\mathrm{a}}$ & $100^{\mathrm{a}}$ & $100^{\mathrm{a}}$ \\
\hline & Boscalid & 0 & 0 & 0 & 0 & 0 & $20^{c}$ & $25^{\mathrm{c}}$ \\
\hline & Azoxystrobin & 0 & 0 & $20^{\mathrm{c}}$ & $24^{\mathrm{b}}$ & $35^{\mathrm{b}}$ & $35^{\mathrm{b}}$ & $36^{\mathrm{b}}$ \\
\hline$C$. & Imazalil & $65^{\mathrm{a}}$ & $68^{\mathrm{a}}$ & $70^{\mathrm{a}}$ & $100^{\mathrm{a}}$ & $100^{\mathrm{a}}$ & $100^{\mathrm{a}}$ & $100^{\mathrm{a}}$ \\
\hline \multirow[t]{2}{*}{ gloeosporioides } & Boscalid & 0 & 0 & 0 & 0 & 0 & $25^{\mathrm{c}}$ & $30^{c}$ \\
\hline & Azoxystrobin & $13^{\mathrm{c}}$ & $22^{\mathrm{c}}$ & $25^{\mathrm{c}}$ & $28^{\mathrm{b}}$ & $35^{\mathrm{b}}$ & $37^{\mathrm{b}}$ & $40^{\mathrm{b}}$ \\
\hline
\end{tabular}

Means having a common letter in the same column are not significantly different at $\mathrm{P}=0.05$ according to Least Significant Difference Test 


\section{DISCUSSION}

A diversity of Colletotrichum species, including C. musae and $C$. gloeosporioides were isolated on bananas showing anthracnose symptoms. These results provide evidence that, in anthracnose pathosystems, the same host is often infected by different Colletotrichum species. Freeman et al (1998) showed that anthracnose of mango was caused by several species of Colletotrichum, including $C$. acutatum $C$. fragariae and C. gloeosporioides. Than et al (2008) also characterized four species of Colletotrichum causes Capsicum spp anthracnose in Thailand. In the present study, the isolation of C. gloeosporioides on bananas showed anthracnose symptoms is justified by the potential of this species to infect a wide range of tropical fruits. C. gloeosporioides is the causative agent of anthracnose of many economically important hosts such as apple, strawberry and avocado (Afanador-Kafuri et al., 2003). Moreover Latiffah et al (2014) showed that $C$. gloeosporioides and C. musae were associated with anthracnose of banana, and C. gloeosporioides was more prevalent than C. musae in Malaysia.

The identification of the isolates based on morphological characteristics showed a variation among Colletotrichum species. C. gloeosporioides isolates exhibited characteristics already described by several authors (Photita et al., 2005; Cannon et al., 2008) allowing their identification. Moreover morphological characters of $C$. musae described in this study are similar to the characters observed by Photita et al. (2005) and Thangamani et al. (2011).

Pathogenicity tests with the Colletotrichum species isolated, showed that all were able to infect and cause symptoms in wounded banana fruit, proving that both species were causal agents of anthracnose infection on banana. This study is the first report in Côte d'Ivoire to highlight the pathogenicity of $C$. gloeosporioides on banana. The results of Latiffah et al (2008) also showed the involvement of C. gloeosporioides in banana anthracnose in Malaysia. The fact that $C$. gloeosporioides was a pathogen of banana confirmed numerous reports about the cross-infection potential among different species of Colletotrichum on a multitude of hosts (Freeman et al., 1998). A difference in virulence was found depending on the inoculated Colletotrichum species. The highest virulence of $C$. musae could be explained by the affinity of this species to banana. $C$. musae has been reported to be the most common causal anthracnose of many banana cultivars (Jinyoung Lim et al., 2002, Priyadarshanie et al., 2015).

Variability in fungicidal sensitivity among the Colletotrichum species was observed. A greater sensitivity of $C$. gloeosporioides to Imazalil was observed compared to $C$. musae which showed moderate sensitivity. The inhibition of ergesterol biosynthesis induced by Imazalil would be more pronounced on $C$. gloeosporioides. This effectiveness of Imazalil was also shown by Andrivon (1997) on Colletotrichum coccodes. However, with Azoxystrobin and Boscalid, marked resistance of both species was noted. The strains of $C$. musae and C. gloeosporioides identified in this study were not be sensitive to these actives ingredients. Resistance to azoxystrobin and boscalid fungicides by fungal pathogens of banana fruits in Côte d'Ivoire may be attributed to continuous and indiscriminate use of these fungicides without rotation or alternating with other fungicides for the control of preharvest and postharvest banana diseases. According to Hobbelen et al. (2013), resistance phenomen occurs after continued use of a fungicide on the target agent. A recent study in Senegal indicated that treatment with azoxystrobin showed no efficacy against post- harvest diseases of banana (Diedhiou et al, 2014).

\section{CONCLUSION}

The results of this study are relevant because, by demonstrating the diversity, virulence and sensitivity to fungicides of Colletotrichum species infecting banana fruits. These results will facilitate the development and implementation of disease management practices, thereby allowing producers to reduce the economic losses in banana production caused by anthracnose.

\section{REFERENCES}

[1] Adams, P. B. and Wong, J. A. L. (1991). The effect of chemical pesticides on the infection of sclerotia of Sclerotinia minor by the biocontrol agent Sporidesmium sclerotivorum. Phytopathology 81:1340-1343.

[2] Afanador-Kafuri L., Minz D., Maymon M., \& Freeman S. (2003). Characterization of Colletotrichum isolates from Tamarillo, Passiflora and Mango in Colombia and identification of a unique species from the genus. Phytopathology, 93, 579-587.

[3] Andrivon D. (1997). Distribution and fungicide sensitivity of Colletotrichum coccodes in French potato-producing areas. Plant pathology, Honolulu, V. 46, pp. $722-728$

[4] Ara, I., H. Rizwana, M.R. Al-Othman and M.A. Bakir (2012). udies of actinomycetes for biological control of Colletotrichum musae pathogen during post harvest anthracnose of banana. Afr. J. Microbiol. Res., 6: 3879-3886.

[5] Bailey J.A., and Jeger M.J. (1992). Colletotrichum: Biology, pathology and control. Wallingford: $\mathrm{CAB}$. 
[6] Cannon P.F., Buddie A.G., and Bridge P. D. (2008). The typification of Colletotrichum gloeosporioides. Mycotaxon, 104, 189-204.

[7] Choi Y. W., Hyde K. D., Ho W. H. (1999). Single spore isolation of fungi. Fungal Divers 3: 29-38

[8] Davet P., Rouxel F. (1997). Détection et isolement des champignons du sol. INRA Paris. Pp 122.

[9] Diedhiou PM, Zakari AH, Mbaye ON, Rokhaya F. and Samb PI: 2014. Control methods for postharvest diseases of banana (Musa sinensis) produced in Senegal. International Journal of Science, Environment and Technology. 3: 1648-1656

[10] Faostat (2016). Food and Agriculture Organization of the United Nations. Statistiques Agricoles : Bananes. https://www. Fao stat3.fao. (Consulté le 12 Novembre 2016).

[11]Freeman S., Katan T., and Shabi E. (1998). Characterization of Colletotrichum species responsible for anthracnose diseases of various fruits. Plant Disease, $82: 596-605$

[12] Gang G. H., Cho H. J., Kim H. S., Kwack Y. B. and Kwak Y. S. (2015). Analysis of fungicide sensitivity and genetic diversity among Colletotrichum species in sweet persimmon. Plant Pathology. J. 31:115-122.

[13] Hobbelen P. H. F., Paveley N. D., Oliver R. P., Van den Bosch F. (2013). The usefulness of concurrent, alternating and mixture use of two high-risk fungicides for delaying the selection of resistance in populations of Mycosphaerella graminicola on winter wheat. Phytopathology 103: 690-707.

[14] Jeffries P., J. C. Dodd M. J. Jeger and R. A. Plumbley (1990). The biology and control of Colletotrichum species on tropical fruit crops. Journal of Plant Pathology, 39: 343-366.

[15]Jinyoung Lim, Thae Heon Lim, Byeongjin Cha (2002). Isolation and Identification of Colletotrichum musae from imported bananas Plant pathology journal 18 (3): 161-164

[16] Kanchana-Udomkan, C., Taylor, P. W. J., \& Mongkolporn, O. (2004). Development of a bioassay to study anthracnose infection of Capsicumm chinense Jacq. fruit caused by Colletotrichum capsici. Thai Journal of Agriculture Science,37, 293-297.

[17]Latiffah Z., Shamsiah, S., Maziah, Z. and Baharuddin, S. (2009). Characterisation of Colletotrichum Species Associated with Anthracnose of Banana. Tropical Life Sciences Research, 20(2) :119-125.

[18]Latiffah Z. Intan Sakinah M. A., Suzianti I. V (2014). Phenotypic and molecular characterization of Colletotrichum species associated with anthracnose of banana (Musa spp) in Malaysia Genetique Molecular. Research. 13 (2) : 3627-3637

[19] Lim JY, Lim TH and Cha B (2002). Isolation and identification of Colletotrichum musae from imported bananas. Plant Pathology Journal 18: 161164.

[20] Murray M.G. and Thompson W.F. (1980). Rapid isolation of high molecular weight plant DNA. Nucleic Acids Research, Carnegie Institution of Washington, Department of Plant Biology, Stanford, CA 94305, USA. (8) 19

[21] Photita W., Taylor P. W. J., Ford R., Hyde K. D., and Lumyong S. (2005). Morphological and molecular characterization of Colletotrichum species from herbaceous plants in Thailand. Fungal Diversity, $18: 117-133$.

[22] Priyadarshanie H., Rasangi K., Vengadaramana A. (2015). Some Preliminary Studies of Colletotrichum musae Associated with Banana Anthracnose Disease in Jaffna District, Sri Lanka Universal Journal of Agricultural Research 3(6): 197-202

[23] Ranasinghe L. S., Jayawardena B., Abeywickrama K., (2005). An integrated strategy to control postharvest decay of Embul banana by combining essential oils with modified atmosphere packaging. International Journal Food Sciences Technology. 40, 97-103

[24] Stover R.H. and Simmonds N.W. (1987). Diseases and disorders. In : Bananas, Longman, pp: 281-323.

[25] Than P. P., Jeewon R., Hyde K. D., Pongsupasamit S., Mongkolporn O., and Taylor P. W. J. (2008). Characterization and pathogenicity of Colletotrichum species associated with anthracnose on chilli (Capsicum spp.) in Thailand. Plant Pathology 57(3) : 562-572.

[26] Thangamani Prema, Ranjitham Prabakar Kuppusamy, Mohammed Faisal Peeran, Kathikeyan Gandhi and Thiruvengadam Raguchander (2011). Morphological and Physiological Characterization of Colletotrichum musae the Causal Organism of Banana Anthracnose World Journal of Agricultural Sciences 7 (6): 743-754,

[27] White T. J., Bruns T., Lee S. and Taylor J.W. (1990). Amplification and direct sequencing of fungal ribosomal RNA genes for phylogenetics. In PCR Protocols, a guide to methods and applications. Edited by Academic Press, New York. Pp 315-322

[28] Young J. R., Tomaso-Peterson M., Tredway L. P. and de la Cerda K., (2010). Occurrence and molecular identification of azoxystrobin-resistant Colletotrichum cereale isolates from golf course putting greens in the Southern United States. Plant Disease. 94 :751-757. 